\title{
The Role of Civil Society in Archaeological Heritage Preservation in the Republic of Moldova
}

\author{
Sergiu Musteață, Iaşi \\ Institute of Archaeology, Romanian Academy, Iasi Branch, Romania
}

Copyright $(2016$ by authors, all rights reserved. Authors agree that this article remains permanently open access under the terms of the Creative Commons Attribution License 4.0 International License

\begin{abstract}
In this paper the author discusses the role of civil society in the preservation of the archaeological heritage in the Republic of Moldova. The Republic of Moldova signed the European Convention on Archaeological Heritage Preservation (revised version) in 1998, ratified it in 2001, and enforced it only since November 2002. But, the national law on archaeological preservation was voted by the Parliament in September 2010 and entered into force in March 2011. So, after a long period of debates and initiatives Republic of Moldova has its own law on this field. The leading role in this process was held by the National Association of Young Historians of Moldova. This NGO initiated in 2009 an advocacy project in the field of cultural heritage preservation. As main goal and result was the elaboration a new law on archaeological heritage preservation, based on international conventions and current trends in the field of archaeological heritage preservation.
\end{abstract}

Keywords Archaeological Heritage Preservation, Civil Society, Republic of Moldova

\section{Introduction}

The National Association of Young Historians of Moldova - Asociația Națională a Tinerilor Istorici din Moldova (ANTIM), founded in 1997, is a non-political, non-profit association, which has the public benefit as purpose. By establishing the ANTIM, its founders primarily wanted to meet a social need, by promoting national and international collaboration of young people that stimulates research activities and helps to preserve our cultural national inheritance. ANTIM is an organization that succeeded to affirm itself through multiple projects that cover various areas of historical research. It is widely recognized for its scientific and practical activities, for the initiation and organization of many symposiums, conferences, summer schools and other ampler academic activities [1]. Among ANTIM's successful activities was the 2009-2010 project "The policy of archaeological heritage preservation in the
Republic of Moldova: reality and necessity", supported by Soros Foundation-Moldova and Swedish Agency for Development and International Cooperation - SIDA. The project included one year advocacy campaign - regional and national meetings, conferences, mass media information activities, publication of leaflets, posters, collection of laws, writing a project of new law on archaeological heritage preservation and its public discussion, including with international experts, etc.

\section{From a Project Idea to a Project Law}

Republic of Moldova became independent in August 1991. Its first law on cultural heritage preservation was approved in 1993 - the law on monuments' preservation. This law is very general and was poorly developed in relation to the archaeological heritage $[9,10,12]$. The most difficult problem was not just the content of the law, but also inefficiency of the state bodies to implement it. For instance, even though the National Register approved in 1993, it was published only in 2010 .

During the last two decades the Republic of Moldova signed many international treaties, and from those ten international and European conventions on cultural heritage, the Republic of Moldova signed in 1998 the Granada and Valletta Conventions. But, signing these Conventions did not change the situation of Moldova in the field of cultural heritage preservation $[11,15,18]$. So, after a decade since our Independence, a group of scholars from the Academy of Sciences of Moldova initiated a new project on cultural heritage preservation, which was not supported by the Government.

In 2005 a group of archaeologists prepared a first draft law project on archaeological heritage preservation, which was discussed for five years in various circles - civil, academic, and even political [2]. In 2009, the National Association of Young Historians of Moldova, as part of an advocacy project, took the initiative to update and promote the draft law project by involving its initial authors and other domestic [3] and foreign archaeologists, managing to propose to the Ministry 
of Culture an updated version in line with contemporary requirements. This project received important feedback and support from colleagues in the United States, Germany, Romania and elsewhere [4, 13].

The project's main purpose was to promote efficient policies for heritage conservation, having the following objectives:

1. Setting a sustainable partnership with the local public administration for the elaboration and implementation of a number of policies to protect the archaeological heritage.

2. Developing a coherent long-term national strategy that would count generally the preservation of cultural and historical heritage and the archaeological heritage, especially among national priorities.

3. Improving the national legal framework, by several adopting laws regarding the protection of archaeological heritage.

4. Discussions with the decision makers about the opportunity of establishing a viable and accountable structure in the field.

The project was launched on May $15^{\text {th }}, 2009$ at the Round Table "Museum policies in Republic of Moldova", with the participation of a wide audience, including specialists from museum network of the country. Immediately after the launch of the project, the working group drafted the activities agenda and tasks were distributed among members. Simultaneously, letters were sent to representatives of local public administrations of Moldova's northern districts that took part in the first seminar of the project. From the beginning were elaborated the leaflet and project's poster, which presented the main information about the project and facilitated the informing of the public about the purposes, objectives and further activities.

During the period May 2009 - May 2010, according to the action plan, a range of activities were performed, structured in three main directions:

\section{A. The analysis and evaluation of protection policies for the archaeological heritage}

The project has been accomplished in two successive stages: at regional and national level. In first stage, we organised three regional meetings (north, centre and south), attended by approximately 100 representatives of local public administration and district museums. These meetings tackled the issue of the real situation in each district, seeking solutions to improve the respective situations. Also, these meetings provided the stage for presenting the objectives and the activities of the project, and witnessed discussions on the projects for a national strategy and the law for archaeological heritage preservation in the Republic of Moldova. The first meeting took place in Bălți on June $16^{\text {th }}, 2009$, the second in Chisinau on October $1^{\text {st }}$, and the third in Cahul, on October $8^{\text {th }}, 2010$.

\section{B. Lobby and promotion of cultural policies changes}

In the second stage there were organised working meetings with the representatives of the Government and Parliament, occasioning discussions on the situation of the archaeological heritage in the Republic of Moldova. The project director and a few members of the working group (Gh. Postică, E. Sava, I. Ştefăniță) had a number of meetings in October with Mr Focşa, the then minister of culture, and discussed about the problems of cultural heritage situation, especially the archaeological heritage. The Draft Law was presented by the Ministry of Culture and further supported by the Government through a decision submitted in Parliament. The round table held on March $9^{\text {th }}, 2010$, discussed the Draft law of archaeological heritage preservation with members of parliamentary the Committee for Culture, Education and Mass Media. The project working team found a real support from the Parliamentary Committee, being ensured of supporting this project to be included in Parliament agenda. Further, after receiving the opinions about the draft law from the Parliamentary Committee, the working group met again with the representatives of the Juridical Committee and the Committee for Culture, Education and Mass Media, where a number of details were embedded into the Draft Law. The final conclusion was that most of the opinions of the parliamentary committees were positive and the suggestions are beneficial for the draft law.

The final conference, which took place on May $20^{\text {th }}, 2010$ and had 40 representatives from different governmental institutions, including from the Ministry of Culture, General Prosecutor, Ministry of Internal Affairs, Chisinau Town Hall, universities and others. Representatives from the Ministry of Internal Affairs and General Prosecutor expressed interest towards the problems that were discussed and stated the availability for further collaboration and exchange of information in the field of cultural heritage preservation in the Republic of Moldova.

\section{Mass-media campaigns}

The project was supported by an information campaign to raise the public awareness of the necessity to adopt an efficient protection policy for archaeological heritage. As such, a series of radio shows were broadcasted, numerous articles were published in the national written mass-media about the problems tackled by the project (copies of the articles attached below). Also, we developed and distributed leaflets, posters and two compilations of normative acts and international conventions that facilitated the disclosure of the population about the problems addressed by the project.

On April $13^{\text {th }}, 2010$, there was organized a round table with the participation of Mr Vitalie Josanu, officer of the heritage police of Neamț County, who presented the experience of Romania in fighting against law infringements that leads to damages or destructions of the historical heritage. The topic attracted mass-media interest and was highly mediatised. 


\section{Final Results}

The following project objectives were met:

1. As a result of the government change in the summer-autumn of 2009, we succeeded to establish a qualitative partnership as some of our experts were appointed to responsible governmental positions that facilitated the achievement of the proposed objectives. This change fortified the relationship with the representatives of local public administration which in the period of communist governance were less receptive to our goals.

2. In agreement with the representatives from the Culture Ministry and the Parliamentary Committee for Culture, we completed the draft law regarding the preservation of archaeological heritage, which was later voted by the Parliament.

3. We elaborated the national strategy project regarding the protection of archaeological heritage and other normative acts, published in a separate compilation, which will serve as a working tool for the staff that activates in this area.

4. Within the project has been proposed the establishment of a National Archaeological Agency. The agency was created by the Government of Republic of Moldova in 2012, the function and responsibilities of which were specified in the law on archaeological heritage preservation.

5. In the framework of the project there were elaborated two compilations of normative acts and international conventions, to serve as working tools for any party interested in the protection of archaeological heritage.

The advocacy campaign successfully raised the public awareness of a number of cases regarding the preservation of archaeological heritage. Specifically, throughout the implementation of the project there were distributed two compilations of normative acts regarding the safety of archaeological heritage:

- Sergiu Musteață (coordinator), Protecția juridică a patrimoniului arheologic. Culegere de acte normative naționale şi convenții internaționale, Chişinău, 2010 (1500 copies) [14];

- Sergiu Musteață (coordinator), Protecția patrimoniului arheologic din Republica Moldova. Culegere de acte normative, Chişinău, 2010 (1000 copies).

\section{Qualitative results}

1. Regional seminars fortified the collaboration with the representatives of local public administration and with museum specialists from different rural locations of the country.

2. Discussions with the representatives of the new central administration Culture Ministry, the Parliamentary Committee for Culture, Education and Mass Media, the Legal Committee led to drawing up a quality draft law, which was supported by the Parliament.

3. Raising awareness of the public, resulting in a high mediatisation of many cases regarding the situation of the cultural heritage, and especially of the archaeological one, in the Republic of Moldova.

4. Referral to investigation authorities (General Prosecutor) regarding the destructions of archaeological traces around the Măzărache Church from Chișinău.

\section{Impact}

The activities performed in the framework of the project had a direct impact on Moldovan society, most notable the establishment of a long-term partnership between many representatives of local public and central administration, with the express goal of promoting a national policy on preserving the archaeological heritage. The media campaign that raised public awareness substantively added to the discussion on a number of problems and cases regarding the destruction and damage brought to the cultural heritage, and the necessity to have an efficient cultural policy. The establishment by the projects of some normative acts (strategies, laws, regulations, etc.) proved the interest of the civil society, academic environment and of some politicians in the implementation of an actual regulatory framework, adapted to international conventions, part of which is also the Republic of Moldova.

Another impact of our activities was the notification of the Ministry of Culture regarding the urgent need to hurry the publication in the Official Monitor of the Republic of Moldova of the Register of monuments under government protection, which even though it was adopted by Parliament in 1993, just as the Law regarding the preservation of monuments, it remained unpublished and did not allow for the application of the legal requirements in cases where the monuments were damaged or destroyed. Seventeen years after, in February 2010, the Register of monuments protected by the government was published in Official Monitor, providing the normative acts needed for protecting the cultural sites.

The Agency for Inspection and Restoration of Monuments initiated the assessment of the government-protected monuments included in the National Register, which will determine their current condition. The first results of these inspections, conducted especially in Chisinau, were widely publicized. Thus, as a result of our project, the Moldovan society was informed about the difficult condition of our archaeological heritage protection and the necessity of intervention by the state institutions.

As result of new Law, the National Agency for Archaeology was established, which because very active, in especially in preventive archaeology. The people employed in the Agency are doing a great job around the country, which is reflected in the new journal Preventive archaeology in the Republic of Moldova. 


\section{Promotion}

One of the project's priorities was the mass-media campaign. Therefore, during the project, an information and public awareness campaign was carried out, which stressed the need for an effective protection of the archaeological heritage. Thus, we managed to achieve a series of interviews on various radio and TV stations, we published several articles in national and district print media, in which were addressed issues concerning the protection of cultural heritage. We also developed, copied and distributed over 1000 leaflets, 1500 posters and 1500 compilations of normative acts and international conventions and a legal guidance in an edition of 1000 copies. All these media activities together, made the project visible and transparent, our actions being sensitized and popularized by various radio, $\mathrm{TV}$ and printed media.

\section{Lessons Learned}

Although ANTIM has an extensive experience in implementation of projects, in the project "Protection policies of the archaeological heritage in Republic of Moldova: reality \& necessity", we have learned useful lessons for our work on, such as:

1. The partnership with state structures may be developed and must be developed continuously, providing quality services, that Local Public Administration and central administration can't or fails to offer.

2. Access to information remains a problem for Moldovan citizens, including the access to information in the field of archaeological heritage protection. That's why the responsible authorities must multiply activities in this direction to improve the situation.

3. Availability of state institutions to collaborate with civil society on an equal level.

\section{Conclusions}

The Law on Archaeological Heritage Preservation was adopted by unanimous vote, including the vote of the communist faction which traditionally being in opposition does not support any democrat initiative, by the Parliament of Republic of Moldova on September $17^{\text {th }}, 2010$ and enacted by Presidential Decree on November $24^{\text {th }}, 2010$ [5]. The Law entered into force three months after its publication in the Official Gazette (Monitorul Oficial) of December $3^{\text {rd }}$, 2010 [6]. Therefore, since March $3^{\text {rd }}, 2011$, the Republic of Moldova has had a new preservation system for its archaeological heritage.

This Law is the first of its kind in the legislation of Moldova and was elaborated according to the Moldovan experience, experts' recommendations, Valletta Convention
(1992), and ICOMOS Charter (1990) [8, 14]. The Law on Archaeological Heritage Preservation of the Republic of Moldova contains 48 articles grouped into 11 chapters [6,7]. The Law on archaeological heritage preservation opens new perspectives for Moldovan society to improve the situation in the field, and to fight black archaeology and illegal trafficking of antiquities [16, 17]. With this Law the Republic of Moldova aligns itself to other European countries and honours, first of all, its commitments taken with signing the Valletta Convention, and second, other European and International field Conventions [18].

The preparation, discussion and the lobby process for the project law on preservation of archaeological heritage undertaken by an NGO initiative and supported by the democratic Government serve as a good practice example of partnership between civil society and state bodies. However, a durable cooperation between these two parts is required in order to improve the situation in the field of archaeological heritage preservation.

\section{Acknowledgements}

This research is part of the Project "Current trends in archaeological heritage preservation: the national and the international perspectives", supported by National Research Council (CNCS) - Executive Agency for Higher Education, Research, Development and Innovation Funding (UEFISCDI), PN-II-ID-PCE-2011-3-0610. Institute of Archaeology of the Romanian Academy, Iasi branch, Romania.

\section{REFERENCES}

[1] More details on ANTIM see on its web page: http://antim.md/

[2] Authors of the 2005 project law were S. Musteață, Gh. Postică, and E. Sava.

[3] Important contributions came from O. Munteanu, I. Tentiuc, V. Vornic, V. Kavruk.

[4] I would like to thank many colleagues from abroad for useful suggestions which helped us improve the law project, including: Paul Shackel, Barbara Little, Uzi Baram (United States of America), Friederich Lüth, Alexandru Popa (Germany), Vasile Chirica, Vitalie Josanu, Viorica Crişan, A.A. Rusu, Eugen Teodor (Romania).

[5] Decree on the enactment of the Law on Archaeological Heritage Preservation, Interim President of the Republic of Moldova Mihai Ghimpu, No. 642-V, 24 November 2010. In: Monitorul Oficial al Republicii Moldova, No. 235-240, Year XVII (376-3773), 3 December 2010, Art. 737, p. 8.

[6] Law on Archaeological Heritage Preservation (no. 218 from 17 September 2010). In: Monitorul Oficial al Republicii Moldova, No. 235-240, Year XVII (376-3773), 3 December 2010, Art. 738, pp. 8-17. 
[7] S. Musteață, A New Law - A New Perspective for Archaeological Heritage Preservation in the Republic of Moldova. In: International Journal of Cultural Property, 2012, 19 (4), 2012, 535-541.

[8] S. Musteață, (ed.), Protecția Patrimoniului, Culegere de Legi şi Convenții [Heritage Preservation. Colleaction of Laws and Conventions], Chişinău, 2001.

[9] S. MusteațǍ, Preservation of the archaeological heritage in the Republic of Moldova. In: Archäologisches Nachrichtenblatt, 12, 4, 2007, 311-322.

[10] S. MusteațĂ, Protecția patrimoniului arheologic. Studiu comparativ: legislația Republicii Moldova şi Statelor Unite ale Americii, [Preservation of the archaeological heritage. Comparative study: the legal framework in the Republic of Moldova and the United States of America]. Monografii ANTIM IV, Chişinău: Pontos, 2008.

[11] S. MusteațĂ, Unele considerații privind Convenția europeană pentru protecția patrimoniului arheologic şi implementarea ei in Republica Moldova [Some considerations of the European Convention for archaeological heritage preservation and its implementation in the Republic of Moldova]. In: A. Gilaş, V. Stepanov (Redactori), Conferința Internațională Ştiințifică „Păstrarea patrimoniului cultural în țările europene" (or. Chişinău, 25-26 octombrie 2008), Chişinău, 2009, 20-32.

[12] S. MusteațĂ, Etica şi deontologia profesională în arheologie [Ethics and professional deontology in archaeology]. In: Tyragetia III (XVIII), nr. 1, 2009, 353-360.
[13] S. MusteațĂ, Let's do our job better and then there will be no reasons to talk about relevancy of archaeology. In: Historical Archaeology 43 (4), 2009, 122-124.

[14] S. Musteață, (ed.), Protecția juridică a patrimoniului arheologic. Culegere de acte normative şi convenții internaționale [Juridical preservation of the archaeological heritage. Collection of the national laws and international conventions], Chişinău, Editura Ruxanda, 2010.

[15] S. MusteațĂ, Cultural Heritage Preservation in the Republic of Moldova between Legal Framework and Reality. In: Civilization Research, No. 8, Tbilisi, 2010, 161-178.

[16] S. MusteațĂ, Looting Antiquities in the Republic of Moldova. In: E. Sava, B. Govedarica, B. Hänsel (Hrsg.), Der Schwarzmeerraum vom Äneolitikum bis in die Frühheisenzeit (5000-500 v.Chr.), Band 2, Globale Entwicklung versus Lolageschichehen. Internationale Fachtagung von Humboldtianer im Humboldt-Kolleg in Chişinău, Moldavien (4. - 8. Oktober 2010), Rehden/Westf., Verlag Marie Leidorf $\mathrm{GmbH}, 2010,279-284$.

[17] S. MusteațĂ, Archaeological heritage crimes in Romania and Moldova: a comparative view. In: Louise Grove and Suzie Thomas (eds), Heritage Crime: Progress, Prospects and Prevention, Palgrave Macmillan, 2014, 2014, 71-80.

[18] S. MusteațĂ, Implementing Valletta Convention in the Republic of Moldova. In: Victoria M. van der Haas and Peter A.C. Schut (eds.), The Valletta Convention: Twenty Years After. Benefits, Problems, Challenges, EAC Occasional Paper 9, Archaeolingua, 2014, 99-104. 